\title{
The Relationship Between Suicide Attempts and Menstrual Cycles in the Emergency Department and the Sociodemographic and Clinical Characteristics of These Patients
}

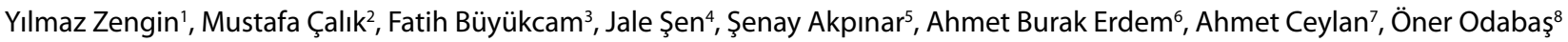 \\ 'Department of Emergency Medicine, Dicle University Faculty of Medicine, Diyarbakır, Turkey \\ ${ }^{2}$ Clinic of Emergency Medicine, Gaziosmanpaşa Taksim Training and Research Hospital, İstanbul, Turkey \\ ${ }^{3}$ Clinic of Emergency Medicine, Dışkapı Yıldırım Beyazıt Training and Research Hospital, Ankara, Turkey \\ ${ }^{4}$ Emergency Service, Dr. I. Şevki Atasagun State Hospital, Nevşehir, Turkey \\ ${ }^{5}$ Emergency Service, Dr. Nafiz Körfez Sincan State Hospital, Ankara, Turkey \\ ${ }^{6}$ Clinic of Emergency Medicine, Ankara Training and Research Hospital, Ankara, Turkey \\ ${ }^{7}$ Emergency Service, Niğde State Hospital, Niğde, Turkey \\ ${ }^{8}$ Department of Urology, Turkey High Specialized Hospital, Ankara, Turkey
}

\begin{abstract}
Aim: Suicidal behavior is defined as choosing death in the conflict between life and death. The aim of this study is to investigate the suspected relationship between suicide attempts and menstrual cycles and to evaluate the sociodemographic and clinical characteristics of the non-pregnant female patients of reproductive age who have presented to our hospital after attempting suicide.
\end{abstract}

Materials and Methods: In this study, 102 female patients (aging 16-45 years) of reproductive age with regular menstrual cycles who presented to the emergency department because of suicide attempts were enrolled. The study was designed as prospective, cross-sectional, and descriptive. The patients' sociodemographic, clinical, and laboratory biochemical parameters were recorded. For the purposes of this study, 100 healthy women who fulfilled the criteria formed the control group and underwent the same procedures as the patient group.

Results: Among the patients who presented to the hospital after attempting suicide, 64 (62.7\%) were in their menstrual period, six (5.9\%) were outside their menstrual period during the follicular phase, five (4.9\%) were at the mid-cycle peak, and 27 (26.4\%) were at the luteal phase, as determined on the basis of the date of their last menstrual period and their blood hormone levels.

Conclusion: The majority of suicide attempts by women occurred during their menstrual period when the estradiol and progesterone levels are at their lowest. (Eurasian JEmerg Med 2015; 14: 118-22)

Keywords: Emergency department, suicide attempt, menstrual cycle

\section{Introduction}

Suicidal behavior is defined as choosing death in the conflict between life and death. Describing the causes leading to suicide and taking the necessary precautions against them may reduce the number of attempted suicides and improve the quality of life of the individuals (1). Although there are various suicide methods, toxic materials are commonly used by the patients who present to the emergency department.

In all the studies, the ratio of suicide attempts was found to be 1.5 times higher among females compared with that among males (2). This condition is attributed to the menstrual cycle and gonadal hormones (3).
In addition, the menstrual cycle has been shown to be associated with the premenstrual syndrome, postpartum psychosis, and depression (4). Few studies have focused on the influence of the gonadal hormone levels on suicide attempts $(5,6)$. However, whether the menstrual cycle is associated with suicide attempts and the phase that makes women more susceptible to them are still under controversy $(7,8)$.

The aim of this study is to investigate the suspected relationship between suicide attempts and the menstrual cycle and to evaluate the sociodemographic and clinical characteristics of the non-pregnant female patients of reproductive age who have presented to our hospital due to an attempted suicide.

Correspondence to: Yılmaz Zengin e-mail: yilmazzengin79@mynet.com 


\section{Materials and Methods}

This study was conducted at Dışkapı Yıldırım Beyazıt Training and Research Hospital from May 5, 2010 to March 15, 2011 at the emergency department after the consent of the ethics committee was obtained (2010/02). This study involved 102 female patients with regular menstrual cycles, who were not pregnant and not using contraceptives, presented because of a suicide attempt, and were of reproductive age (aging 16-45 years). The patients filled out their information and consent forms.

The study was designed as prospective, cross-sectional, and descriptive. For the purposes of this study, 100 healthy women who fulfilled the criteria formed the control group and underwent the same procedures as the patient group.

Female patients outside their reproductive age (their menstrual cycle had not started or they were menopausal), pregnant women, patients who were dead at the time of arrival to the hospital, and patients on oral contraceptives were excluded from the study.

Following the patients' first treatment in the emergency department, the following factors were recorded: the time of presentation to the hospital, age, profession, educational status, marital status, number of children, place of residence, manner of presentation to the medical facility, patient history, history of smoking and alcohol or substance abuse, cause of suicide, method of suicide, active ingredient used and its dose, lethal danger, duration of follow-up, date of the last menstrual period, menstrual data (age of menarche, cycle regularity, frequency, and duration), and use of contraception. In addition, the blood beta human chorionic gonadotropin, follicle-stimulating hormone (FSH), luteinizing hormone (LH), estradiol, and progesterone levels were measured using the Siemens Immulite hormone assay device by the chemiluminescence immunoassay (LEIA) method. The patients' biochemical parameters (glucose, urea, creatinine, alanine transaminase, aspartate aminotransferase, sodium, potassium, chloride, and calcium levels) were also recorded.

Regarding the hormone measurements, to detect the menstrual phase for patients and control group, serum LH, FSH, progesterone, and estradiol levels were measured within $24 \mathrm{~h}$ of the attempt, as defined in the previous studies $(5,9)$. Menstrual phase was determined using the following algorithm $(6,9)$ : those with progesterone levels $>2.3 \mathrm{ng} / \mathrm{mL}$ were classified as being in the luteal phase; those with FSH levels between 5.7 and $20 \mathrm{mIU} / \mathrm{mL}$, LH levels between 15 and 62 $\mathrm{mlU} / \mathrm{mL}$, and progesterone levels $(62.3 \mathrm{ng} / \mathrm{mL})$ were classified as being in mid-cycle; and those with low levels of FSH (3.4-10 mlU/mL), $\mathrm{LH}(1.6-8.3 \mathrm{mlU} / \mathrm{mL})$, and progesterone $(0-1.5 \mathrm{ng} / \mathrm{mL})$ were classified as being in the follicular phase.

Among the patients included in this study, their menstrual cycle was determined on the basis of the date of their last menstrual period and their blood hormone levels. The patients and control groups were divided in four subgroups for menstrual phases.

\section{Statistical analysis}

The statistical analysis was performed using the Statistical Package for the Social Sciences (SPSS Inc., Chicago, IL, USA) version 18.0 software. The normality of the distribution of continuous variables was investigated using the independent samples t-test. The descriptive statistics are presented as mean \pm standard deviation or median (minimum-maximum) for the continuous variables and number and percentage of cases for nominal variables. Because the numeric variables did not show a normal distribution, the Mann-Whitney $U$ test was used and statistical significance was based on a value of $p<0.05$.

\section{Results}

The sociodemographic and clinical characteristics of the patients in this study are presented in Table 1. Depending on the active ingredient and its dose and according to the follow-up periods recommended by toxicology, 14 patients (13.7\%) were followed up for 12 h, 72 patients $(70.6 \%)$ for 24 h, 14 patients (13.7\%) for 48 h, and two patients $(2.0 \%)$ for $72 \mathrm{~h}$.

In terms of the length of the follow-ups in the emergency department observation unit, among 67 patients (65.6\%), the minimum length of their hospital stay was 1 day, the maximum was 8 days, and the mean was 2.1 days. Although some of the patients had severe toxic findings and symptoms, all the patients were discharged and made a complete recovery.

The hormone levels (FSH, $\mathrm{LH}$, estradiol, and progesterone) of the patients according to their menstrual cycle are presented in Table 2.

In this study, 64 (62.7\%) patients were in their menstrual phase, six (5.9\%) were outside their menstrual phase during the follicular phase, five (4.9\%) were at the mid-cycle phase, and 27 (26.4\%) were in the luteal phase of the menstrual cycle determined on the basis of the date of their last menstrual period and their blood hormone levels. The days of the patients' menstrual cycle were four (3.9\%) on their first day, 23 (22.3\%) on their second day, 23 (22.3\%) on their third day, seven $(6.8 \%)$ on their fourth day, two $(1.9 \%)$ on their fifth day, four (3.9\%) on their sixth day, and one (1\%) on the seventh day.

The estrogen and progesterone levels in the phases of the menstrual cycle were statistically different between the patients and the controls (estrogen, $p<0.001$; progesterone, $p=0.016$; Table 2 ).

\section{Discussion}

Suicide-a major problem faced by all societies-is among the top 10 causes of death in the world and suicide rates vary among countries $(10,11)$. However, there were no major differences in our study concerning the clinical and sociodemographic characteristics of the patients in previous studies. There was a significant relationship between suicide attempts and the menstrual cycle, and the majority of patients who attempted suicide were in their menstrual phase of the menstrual cycle.

Ozdel et al. (12) reported that the suicides were attempted between $6: 00$ p.m. and midnight in $47.5 \%$ of the cases, whereas they were attempted between 12:00 p.m. and 6:00 p.m. in 37.5\% of the cases. Similarly, Guloglu et al. (13) reported that the majority of the suicide attempts (26.6\%) occurred between 6:00 p.m. and midnight in a study comprising 1,281 patients. In our study, the majority of the patients admitted to the emergency department had attempted suicide between 6:00 p.m. and midnight. We consider that these situations are associated with this timing with the aim of attracting the attention of the people nearby and to receive their help.

Studies from our country reported that suicide attempts were more common among housewives and students (14, 15). Nevertheless, Senol et al. (10) observed that $54 \%$ of the patients were single. In our study, the majority of the patients who attempted suicide were individuals without financial independence, such as housewives or students, and their marital status was single. We therefore suggest that marriage has a strong protective effect against suicide attempts.

A history of psychiatric disorders, particularly depression, among patients who have attempted suicide, has been reported to be a factor paving the way for suicide $(16,17)$. In a study by Bekaroglu et al. (18), $36 \%$ of the patients who attempted suicide were found to have a history of psychiatric disorders. In the study by Cheng et al. (19), de- 
Table 1. Sociodemographic and clinical features of patients according to the menstrual cycle phases

\begin{tabular}{|c|c|c|c|c|c|}
\hline & \multirow[b]{2}{*}{ Total $(n=102)$} & \multicolumn{2}{|c|}{ Follicular phase $(n=70)$} & \multirow[b]{2}{*}{$\begin{array}{l}\text { Mid cyclic phase } \\
\qquad(n=5)\end{array}$} & \multirow[b]{2}{*}{$\begin{array}{l}\text { Luteal phase } \\
\qquad(n=27)\end{array}$} \\
\hline & & $\begin{array}{c}\text { Menstrual phase } \\
(n=64)\end{array}$ & $\begin{array}{c}\text { Non-menstrual } \\
\text { phase }(n=6)\end{array}$ & & \\
\hline Age (years, mean \pm SD) & $25.56 \pm 8.19$ & $25.95 \pm 8.39$ & $30 \pm 9.85$ & $22.8 \pm 4.96$ & $24.03 \pm 7.60$ \\
\hline $\begin{array}{l}\text { First menstruation age } \\
\text { (years, mean } \pm S D \text { ) }\end{array}$ & $12.17 \pm 0.61$ & $12.10 \pm 0.64$ & $12 \pm 0.63$ & $12.6 \pm 0.54$ & $12.29 \pm 0.54$ \\
\hline \multicolumn{6}{|l|}{ Marital status, n (\%) } \\
\hline Married & $41(40.1)$ & $28(43.7)$ & $4(66.6)$ & $4(80)$ & $5(18.5)$ \\
\hline Single & $57(55.8)$ & $33(51.5)$ & $2(33.3)$ & $1(20)$ & $21(77.8)$ \\
\hline Other & $4(4.1)$ & $3(4.8)$ & $0(0)$ & $0(0)$ & $1(3.7)$ \\
\hline Having children, n (\%) & $37(36.2)$ & $27(42.1)$ & $3(50)$ & $2(40)$ & $5(18.5)$ \\
\hline $\begin{array}{l}\text { Number of children } \\
(\text { mean } \pm \text { SD) }\end{array}$ & $0.7 \pm 1.0$ & $0.8 \pm 1.1$ & $1.0 \pm 1.2$ & $0.8 \pm 0.8$ & $0.4 \pm 0.9$ \\
\hline \multicolumn{6}{|l|}{ Occupation, n (\%) } \\
\hline Housewife & $63(61.7)$ & $39(60.9)$ & $4(66.6)$ & $4(80)$ & $16(59.2)$ \\
\hline Student & $27(26.4)$ & $18(28.1)$ & $0(0)$ & $1(20)$ & $8(29.6)$ \\
\hline Worker & $12(11.9)$ & $7(11.0)$ & $2(33.3)$ & $0(0)$ & $3(11.2)$ \\
\hline \multicolumn{6}{|l|}{ Education levels, n (\%) } \\
\hline First school & $16(15.6)$ & $12(18.7)$ & $2(33.3)$ & $0(0)$ & $2(7.4)$ \\
\hline Secondary school & $17(16.6)$ & $6(9.3)$ & $0(0)$ & $3(60)$ & $8(29.6)$ \\
\hline High school & $61(59.8)$ & $41(64.1)$ & $2(33.3)$ & $2(40)$ & $16(59.3)$ \\
\hline University & $8(8.0)$ & $5(7.9)$ & $2(33.3)$ & $0(0)$ & $1(3.7)$ \\
\hline \multicolumn{6}{|l|}{ Time of ED admission, n (\%) } \\
\hline 00:00-06:00 & $23(22.5)$ & $14(21.8)$ & $3(50)$ & $1(20)$ & $5(18.5)$ \\
\hline 06:00-12:00 & $14(13.7)$ & $8(12.5)$ & $1(16.6)$ & $1(20)$ & $4(14.8)$ \\
\hline $12: 00-18: 00$ & $26(25.4)$ & $18(28.1)$ & $0(0)$ & $1(20)$ & $7(25.9)$ \\
\hline $18: 00-24: 00$ & $39(38.4)$ & $24(37.6)$ & $2(33.4)$ & $2(40)$ & $11(40.8)$ \\
\hline \multicolumn{6}{|l|}{ Medical history, n (\%) } \\
\hline HT & $1(0.9)$ & $1(1.5)$ & $0(0)$ & $0(0)$ & $0(0)$ \\
\hline DM & $1(0.9)$ & $0(0)$ & $0(0)$ & $0(0)$ & $1(3.7)$ \\
\hline CAD & $1(0.9)$ & $1(1.5)$ & $0(0)$ & $0(0)$ & $0(0)$ \\
\hline COPD & $1(0.9)$ & $1(1.5)$ & $0(0)$ & $0(0)$ & $0(0)$ \\
\hline Epilepsy & $9(8.8)$ & $4(6.2)$ & $1(16.6)$ & $0(0)$ & $4(14.8)$ \\
\hline Other & $1(0.9)$ & $0(0)$ & $0(0)$ & $0(0)$ & $1(3.7)$ \\
\hline \multicolumn{6}{|l|}{ Psychiatry history, n (\%) } \\
\hline Depression & $18(17.6)$ & $10(15.6)$ & $2(33.3)$ & $1(20)$ & $5(18.5)$ \\
\hline Adjustment disorders & $7(6.8)$ & $4(6.2)$ & $0(0)$ & $0(0)$ & $3(11.2)$ \\
\hline Anxiety & $3(2.9)$ & $2(3.1)$ & $0(0)$ & $0(0)$ & $1(3.7)$ \\
\hline Schizophrenia & $3(2.9)$ & $2(3.1)$ & $0(0)$ & $0(0)$ & $1(3.7)$ \\
\hline Bipolar disorders & $2(1.9)$ & $1(1.5)$ & $0(0)$ & $0(0)$ & $1(3.7)$ \\
\hline Other & $3(2.9)$ & $2(3.1)$ & $0(0)$ & $0(0)$ & $1(3.7)$ \\
\hline
\end{tabular}


Table 1 (Continue). Sociodemographic and clinical features of patients according to the menstrual cycle phases

\begin{tabular}{|c|c|c|c|c|c|}
\hline & \multirow[b]{2}{*}{ Total $(n=102)$} & \multicolumn{2}{|c|}{ Follicular phase $(n=70)$} & \multirow[b]{2}{*}{$\begin{array}{l}\text { Mid cyclic phase } \\
\qquad(\mathrm{n}=5)\end{array}$} & \multirow[b]{2}{*}{$\begin{array}{c}\text { Luteal phase } \\
\quad(n=27)\end{array}$} \\
\hline & & $\begin{array}{c}\text { Menstrual phase } \\
(n=64)\end{array}$ & $\begin{array}{c}\text { Non-menstrual } \\
\text { phase }(n=6)\end{array}$ & & \\
\hline \multicolumn{6}{|l|}{$\begin{array}{l}\text { Substances used in suicide } \\
\text { Attempts, } \mathrm{n}(\%)\end{array}$} \\
\hline Multidrug & $30(29.4)$ & $20(31,2)$ & $0(0)$ & $1(20)$ & $9(33.4)$ \\
\hline Analgesics & $28(27.5)$ & $21(32.9)$ & $2(33.3)$ & $1(20)$ & $4(14.8)$ \\
\hline Psychiatric drugs & $24(23.5)$ & $14(21.9)$ & $1(16.6)$ & $3(60)$ & $6(22.2)$ \\
\hline Diabetic drugs & $5(4.9)$ & $2(3.1)$ & $1(16.6)$ & $0(0)$ & $2(7.4)$ \\
\hline Antibiotics & $4(3.9)$ & $1(1.5)$ & $1(16.6)$ & $0(0)$ & $2(7.4)$ \\
\hline Cardiac drugs & $2(1.9)$ & $0(0)$ & $0(0)$ & $0(0)$ & $2(7.4)$ \\
\hline Other & $9(8.9)$ & $6(9.4)$ & $1(16.6)$ & $0(0)$ & $2(7.4)$ \\
\hline \multicolumn{6}{|l|}{ Substance use, n (\%) } \\
\hline Cigarette & $71(69.6)$ & $46(71.8)$ & $6(100)$ & $4(80)$ & $15(55.5)$ \\
\hline Alcohol & $12(11.9)$ & $10(15.6)$ & $1(16.6)$ & $0(0)$ & $1(3.7)$ \\
\hline $\begin{array}{l}\text { Previous suicide attempt, } \\
\mathrm{n}(\%)\end{array}$ & $15(14.7)$ & $12(18.7)$ & $0(0)$ & $1(20)$ & $2(7.4)$ \\
\hline \multicolumn{6}{|l|}{ Suicidal reasons, n (\%) } \\
\hline Mental depression & $48(46.9)$ & $31(48.4)$ & $4(66.8)$ & $2(40)$ & $11(40.7)$ \\
\hline Emotional affairs & $30(29.4)$ & $18(28.1)$ & $1(16.6)$ & $0(0)$ & $11(40.7)$ \\
\hline Economic causes & $11(10.7)$ & $8(12.5)$ & $0(0)$ & $3(60)$ & $0(0)$ \\
\hline Domestic violence & $8(8.0)$ & $5(7.9)$ & $1(16.6)$ & $0(0)$ & $2(7.4)$ \\
\hline Failure of education & $4(4.1)$ & $2(3.1)$ & $0(0)$ & $0(0)$ & $2(7.4)$ \\
\hline Health problems & $1(0.9)$ & $0(0)$ & $0(0)$ & $0(0)$ & $1(3.7)$ \\
\hline \multicolumn{6}{|l|}{ Hormone levels (mean \pm SD) } \\
\hline $\mathrm{FSH}(\mathrm{mlU} / \mathrm{mL})$ & $7.8 \pm 10.9$ & $8.1 \pm 10.5$ & $21.6 \pm 25.6$ & $7.8 \pm 3.6$ & $4.0 \pm 1.7$ \\
\hline $\mathrm{LH}(\mathrm{mlU} / \mathrm{mL})$ & $8.9 \pm 9.6$ & $8.9 \pm 7.5$ & $12.9 \pm 9.6$ & $32.5 \pm 18.1$ & $3.6 \pm 2.6$ \\
\hline Estradiol (pg/mL) & $175.4 \pm 81.7$ & $73.5 \pm 65.7$ & $35.8 \pm 15.3$ & $230.1 \pm 73.5$ & $104.8 \pm 74.2$ \\
\hline Progesterone $(\mathrm{ng} / \mathrm{mL})$ & $2.7 \pm 2.6$ & $0.8 \pm 0.5$ & $1.08 \pm 0.8$ & $1.5 \pm 0.7$ & $6.4 \pm 2.8$ \\
\hline
\end{tabular}

pressive disorders were diagnosed as the most frequent psychiatric condition, with a $48.3 \%$ ratio among the patients who attempted suicide. In our study, approximately one-third of the patients had psychiatric disorders and nearly half of them had depressive disorders. Therefore, we believe that patients with depression should be treated and followed up closely by their families and relevant officials.

Sogut et al. (20) reported that the most common causes for suicide are depression (45.3\%), domestic violence (24.2\%), and emotional relationships. In our study, the most commonly observed cause was depression, followed by emotional relationships, and this result may be associated with the characteristics of the patient group.

In the study by Andersen et al. (21), the most commonly used active ingredients in suicide attempts were analgesics, antidepressants, antipsychotics, and cardiovascular drugs. In a study conducted on 2,388 patients in the Cukurova region between January 1, 1997 and December 31, 2002, 426 of the patients (32.4\%) had taken multiple drugs (22). In our study, the majority of the patients had taken multiple drugs, followed by analgesics and antipsychotics for their
Table 2. The hormone levels of suicide patients and control group

\begin{tabular}{|c|c|c|c|}
\hline $\begin{array}{l}\text { Parameters } \\
\text { (mean } \pm S D)\end{array}$ & $\begin{array}{l}\text { Control group } \\
(n=100)\end{array}$ & $\begin{array}{c}\text { Suicide patients } \\
\quad(n=102)\end{array}$ & p* \\
\hline $\mathrm{FSH}(\mathrm{mlU} / \mathrm{mL})$ & $8.28 \pm 3.49$ & $7.84 \pm 10.90$ & $<0.001$ \\
\hline $\mathrm{LH}(\mathrm{mlU} / \mathrm{mL})$ & $20.15 \pm 15.17$ & $8.93 \pm 9.68$ & $<0.001$ \\
\hline Estradiol (pg/mL) & $87.28 \pm 75.57$ & $175.44 \pm 81.70$ & $<0.001$ \\
\hline Progesteron (ng/mL) & $2.36 \pm 2.90$ & $2.77 \pm 2.65$ & 0.016 \\
\hline
\end{tabular}

suicide attempts. We believe that obtaining these drugs is easy in our country and therefore drug overdoses should be prevented.

In the study conducted by Cayköylü et al. (7) in 2004, 42.3\% of the 52 attempted suicide patients with regular menstrual cycles made their suicide attempts during their menstrual period, followed by $25 \%$ who attempted their suicides during the luteal phase. In a lat- 
er study by Baca-Garcia et al. (8), 72 of the 281 patients (26\%) reportedly attempted suicide during their menstrual period. Although the menstrual phase comprises 6-7 days of the 28-day menstrual cycle, in our study, the great majority of the patients were in the menstrual phase of their cycle. Hence, we suggested that the menstrual cycle may trigger suicide attempts.

Estradiol enhances the serotonin synthesis and may increase the serotonin levels by changing the serotonin receptor balance and decreasing the serotonin metabolism through the inhibition of monoamine oxidase $A$ (8). In a study, estradiol was found to increase the expression of serotonin transporter mRNA in the brain (23). Moreover, in a postmortem study on suicide victims, the serotonin transporter ligands in the dorsal raphe nucleus were observed as having been modified. Based on these results, researchers have suggested that the low estradiol levels contributed to a reduction in the serotonergic nerve conduction, and this may be the underlying cause of the relationship between menstruation and suicidal behavior (6). We believe that the majority of patients with low estrogen levels are in their menstrual phase, which suggests that their suicide attempts are related to their menstrual cycle.

Studd et al. (24) have demonstrated in their study that low progesterone levels are associated with higher rates of suicidal thoughts in adult women. Because the majority of the patients in our study were in their menstrual period phase and had their lowest estradiol and progesterone levels compared with the other time points in their menstrual cycle, we believe that there is a significant relationship between suicide attempts and the menstrual cycle. However, this relationship may not just be hormonal and may also be associated with the physical limitations women experience during their periods and their social and psychological impact. This study may support wider patient and physician awareness of this high-risk term for suicide attempts and finally reduce the morbidity and mortality related to these attempts.

\section{Study limitations}

The limitation of our study is that it is a single-center study.

\section{Conclusion}

The majority of suicide attempts by women occur during their menstrual period when their estradiol and progesterone levels are the lowest. Therefore, a kinder approach to women during this time may reduce their rate of suicide attempts.

Ethics Committee Approval: Ethics committee approval was received for this study from the ethics committee of Dışkapı Yıldırım Beyazıt Training and Research Hospital.

Informed Consent: Written informed consent was obtained from patients who participated in this study.

Peer-review: Externally peer-reviewed.

Conflict of Interest: No conflict of interest was declared by the authors.

Financial Disclosure: The authors declared that this study has received no financial support.

\section{References}

1. Kekeç Z, Yıldııım C, Ikizceli İ, Gönül AS, Sözüer EM. Özkıyım girişimi nedeniyle acil servise başvuran hastalarda hazırlayıcı etkenler. Anadolu Psikiyatri Derg 2000; 1: 157-61.
2. Mitchell AM, Garand L, Dean D, Panzak G, Taylor M. Suicide Assessment in Hospital Emergency Departments: Implications for Patient Satisfaction and Compliance. Top Emerg Med 2005; 27: 302-12.

3. Parry BL, Newton RP. Chronobiological basis of female-specific mood disorders. Neuropsychopharmacology 2001; 25(5 Suppl): S102-8. [CrossRef]

4. Akdeniz F, Karadağ F. Does menstrual cycle affect mood disorders? Turk Psikiyatri Derg 2006; 17: 296-304.

5. Baca-Garcia E, Diaz-Sastre C, Ceverino A, Saiz-Ruiz J, Diaz FJ, De Leon J. Association between the menses and suicide attempts: a replication study. Psychosom Med 2003; 65: 237-44. [CrossRef]

6. Saunders KE, Hawton K. Suicidal behaviour and the menstrual cycle. Psychol Med 2006; 36: 901-12. [CrossRef]

7. Cayköylü A, Capoglu I, Oztürk I. The possible factors affecting suicide attempts in the different phases of the menstrual cycle. Psychiatry Clin Neurosci 2004; 58: 460-4. [CrossRef]

8. Baca-Garcia E, Diaz-Sastre C, Ceverino A, Perez-Rodriguez MM, Navarro-Jimenez R, Lopez-Castroman J, et al. Suicide attempts among women during low estradiol/low progesterone states. J Psychiatr Res 2010; 44: 209-14. [CrossRef]

9. Becker JB, Arnold AP, Berkley KJ, Blaustein JD, Eckel LA, Hampson E, et al. Strategies and methods for research on sex differences in brain and behavior. Endocrinology 2005; 146: 1650-73. [CrossRef]

10. Şenol V, Ünalan D, Avşaroğulları L, İkizceli İ. İntihar girişimi nedeniyle Erciyes Üniversitesi Tıp Fakültesi Acil Anabilim Dalına başvuran olguların incelenmesi. Anadolu Psikiyatri Derg 2005; 6: 19-29.

11. Skegg K. Self-Harm. Lancet 2005; 366: 1471-83. [CrossRef]

12. Ozdel O, Varma G, Atesci FC, Oguzhanoglu NK, Karadag F, AmukT. Characteristics of suicidal behavior in a Turkish sample. Crisis 2009; 30: 90-3. [CrossRef]

13. Güloğlu C, Gökhan Ş, Üstündağ $M$, Orak M. Acil servise başvuran olguların kullandıkları yöntemler ve demografik verilerin mortalite ile ilişkisi. Türkiye Acil Tıp Dergisi 2009; 9: 109-14.

14. Pelkonen M, Marttunen M. Child and adolescent suicide: epidemiology, risk factors, and approaches to prevention. Paediatr Drugs 2003; 5: 24365. [CrossRef]

15. Sayıl I. İntihar Davranışı ve epidemiyolojisi. Psikiyatrik Epidemiyoloji (Ed) Doğan O. Ege Psikiyatri Yayınları, İzmir, 2002: 118-23.

16. Kuo WH, Gallo JJ, Tien AY. Incidence of suicide ideation and attempts in adults: the 13-year follow-up a community sample in Baltimore, Maryland. Psychol Med 2001; 31: 1181-91. [CrossRef]

17. Nordentoft M. Prevention of suicide and attempted suicide in Denmark. Epidemiological studies of suicide and intervention studies in selected risk groups. Dan Med Bull 2007; 54: 306-69.

18. Bekaroğlu M, Bilici M, Hocaoğlu Ç, Gürpınar S, Uluutku N. Trabzon'da 1995 yılı intihar girişimi insidansı. Türk Psikiyatri Dergisi 2000; 11: 95-102.

19. Cheng AT, Chen THH, Chen CC, Jenkins R. Psychosocial and psychiatric risk factors for suicide. Br J Psychiatry 2000; 177: 360-5. [CrossRef]

20. Söğüt Ö, Sayhan MB, Gökdemir MT, Kaya H, Al B, Orak M, Üstündağ M. Evaluation of suicide attempts in Southeast of Turkey, around the Sanliurfa Region. Eurasian J Emerg Med 2011; 10: 8-6.

21. Andersen UA, Andersen M, Rosolm JU, Gram LF. Psychopharmacological treatment and psychiatric morbidity in 390 cases of suicide with special focus on affective disorders. Acta Psychiatr Scand 2001; 104: 458-65. [CrossRef]

22. Seydaoglu G, Satar S, Alparslan N. Frequency and mortality risk factors of acute adult poisoning in Adana, Turkey, 1997-2002. Mt Sinai J Med 2005; 72: 393-401.

23. Borrow AP, Cameron NM. Estrogenic mediation of serotonergic and neurotrophic systems: implications for female mood disorders. Prog Neuropsychopharmacol Biol Psychiatry 2014; 54: 13-25. [CrossRef]

24. Studd J, Nappi RE. Reproductive depression. Gynecol Endocrinol 2012; 28: 42-5. [CrossRef] 